\title{
PENINGKATAN NILAI EKONOMI MELON MELALUI PENGEMBANGAN PRODUK OLAHAN MELON UNTUK MENINGKATKAN PENDAPATAN MASYARAKAT DI DESA GUMANTAR KECAMATAN KAYANGAN KABUPATEN LOMBOK UTARA
}

\author{
Rini Nofrida ${ }^{*}$, Zainuri, Yeni Sulastri, Rucitra Widyasari, dan Abas Zaini \\ Program Studi Ilmu dan Teknologi Pangan Fakultas Teknologi Pangan dan Agroindustri \\ Universitas Mataram \\ ${ }^{*}$ Korespondensi: rininofrida@unram.ac.id
}

Diterima 5 November 2018 / Disetujui 2 Desember 2018

\begin{abstract}
ABSTRAK
Desa Gumantar yang terletak di Kecamatan Kayangan, Kabupaten Lombok Utara mempunyai potensi hasil pertanian hortikultura yang besar dengan beragam jenis komoditas pertanian, salah satunya adalah melon. Selama ini masyarakat menjual sebagian besar buah melonnya dalam bentuk buah melon segar sehingga hasil yang diperoleh relatif rendah. Buah melon mempunyai peluang diolah lebih lanjut menjadi produk olahan pangan yang dapat memberikan nilai tambah sehingga penerimaan petani atau masyarakat dari usaha pengembangan komoditas melon ini menjadi meningkat. Oleh karena itu, perlu dilakukan kegiatan pelatihan pengolahan buah melon menjadi produk olahan bermutu dan bernilai ekonomi. Kegiatan pelatihan tersebut telah dilakukan sebagai rangkaian dari kegiatan pengabdian kepada masyarakat dosen Fakultas Teknologi Pangan dan Agroindustri Universitas Mataram di Desa Gumantar, Kecamatan Kayangan Kabupaten Lombok Utara. Kelompok masyarakat yang terdiri atas ibu Kelompok Wanita Tani (KWT) diberikan pelatihan tentang cara pengolahan buah melon dengan menerapkan prinsip cara pengolahan yang baik dan benar dalam rangka menghasilkan produk olahan yang bermutu dan aman serta memenuhi syarat standar nasional untuk pangan. Selain itu materi tentang pengemasan dan perijinan serta peluang pasar produk melon juga diberikan pada saat pelatihan sebagai upaya untuk menghasilkan produk yang berdaya saing sehingga dapat meningkatkan nilai tambah dan nilai ekonomi melon.
\end{abstract}

Kata kunci: Desa Gumantar, nilai ekonomi, produk olahan melon

\section{PENDAHULUAN}

Desa Gumantar yang terletak di Kecamatan Kayangan, Kabupaten Lombok Utara adalah salah satu desa yang memiliki banyak potensi alam. Kondisi topografi Desa Gumantar merupakan daerah perbukitan dan persawahan dekat pesisir dengan kondisi infrasturktur jalan transportasi yang cukup baik. Wilayah Desa Gumantar sendiri memiliki potensi yang cukup memadai untuk dikembangkan, khususnya di bidang pertanian hortikultuta yaitu buah dan sayur. Salah satu buah yang banyak 
terdapat di dusun ini adalah melon. Banyak petani yang membudidayakan melon, sehingga ketika musim panen, jumlah melon yang dihasilkan oleh daerah ini cukup berlimpah.

Melon merupakan salah satu komoditas buah yang banyak digemari masyarakat. Selama ini petani di desa Gumantar menjual langsung buah melonnya ke pengepul. Margin yang didapatkan akan besar ketika produksi melon tidak begitu berlimpah, akan tetapi ketika produksi banyak jumlah margin keutungan yang didapatkan petani lebih kecil. Ketika musim panen, jumlah melon yang rusak juga menjadi kendala bagi petani, kerusakan melon diakibatkan keterlambatan penjualan ataupun karena melimpahnya produksi sehingga terjadi penumpukan. Salah satu cara yang dapat dilakukan untuk meningkatkan margin keuntungan penjualan melon bagi petani dan juga pencegahan penumpukan dan kerusakan melon setelah panen adalah dengan cara melakukan pengolahan buah melon menjadi produk yang memiliki nilai jual yang lebih tinggi. Salah satu roduk yang bisa di produksi sebagai alternatif pengolahan melon adalah permen jelly. Prinsip pembuatan permen jelly sangat sederhana, yaitu dengan mencampurkan bubur buah melon dengan bubuk agaraagar kemudian dikeringkan. Teknologi yang sederhana dan proses yang relatif cepat dapat dengan mudah diadaptasi oleh petani. Permen jelly melon dirasa dapat menjadi solusi yang tepat karena selain meningkatkan umur simpan juga dapat memperluas pasar.

Selain penyuluhan proses pengolahan, pengabdian dirancang secara menyeluruh yaitu desain kemasan yang menarik dan sesuai standar dilengkapi dengan contoh pelabelan, juga penyuluhan mengenai P-IRT dan sanitasi secara keseluruhan sehingga hasil penyuluhan dapat dilaksanakan secara berkelanjutan.

\section{METODE KEGIATAN}

\section{Waktu dan Lokasi}

Kegiatan pengabdian dilaksanakan pada bulan September 2018 . Lokasi kegiatan sesuai dengan potensi bahan baku di lokasi mitra yaitu di Desa Gumantar Kecamatan Kayangan Kabupaten Lombok Utara.

\section{Alat dan Bahan}

Peralatan yang digunakan dalam kegiatan ini berupa alat pengolahan dan kemasan untuk mengolah melon menjadi permen jelly melon yang terdiri dari: hand sealer, kompor, panci, kemasan plastik, pisau, alat pencetak jelly, timbangan, dan label. Bahan baku yang digunakan untuk pengolahan permen jelly melon berupa melon, gula, air, perisa melon, asam sitrat dan sedikit garam.

\section{Metode Pelaksanaan}




Kegiatan pengabdian kepada
masyarakat ini dilakukan melalui
serangkaian tahapan kegiatan yang
meliputi optimasi dan pembuatan contoh produk di laboratorium lalu dilanjutkan dengan pelatihan kepada masyarakat. Kegiatan pelatihan tersebut dilakukan dengan metode ceramah, diskusi, dan dilanjutkan dengan praktek pembuatan produk olahan melon yaitu permen jelly melon. Materi pelatihan yang diberikan meliputi cara pembuatan permen jelly melon yang bermutu, teknik pengemasan produk, perijinan dan strategi pemasaran produk aneka olahan melon.

Evalusi kegiatan dilakukan dengan melihat tanggapan peserta dan kemampuan penguasaan materi yang telah diberikan. Tanggapan dan penguasaan materi diukur dengan kehadiran peserta, memantau pertanyaan yang disampaikan peserta kepada penyaji materi, serta keaktifan peserta saat melakukan praktek pembuatan aneka olahan melon.

\section{HASIL DAN PEMBAHASAN}

\section{Optimasi dan Penyiapan Contoh Produk Olahan Melon}

Sebagai tahapan awal dalam pelaksanaan kegiatan pengabdian ini adalah tim melakukan optimasi teknologi pengolahan dan penyiapan contoh produk olahan melon di Laboratorium Pengolahan Pangan Fakultas Teknologi Pangan dan Agroindustri Universitas Mataram. Produk olahan melon yang disiapkan adalah permen jelly melon. Kegiatan ini sangat penting agar dapat diperoleh prosedur pengolahan yang tepat dan dapat dihasilkan permen jelly melon yang bermutu.

\section{Pelatihan Pengolahan Melon Menjadi Produk Bernilai Ekonomi}

Kegiatan pengabdian yang terdiri atas dua tahapan yaitu pemaparan materi lalu dilanjutkan dengan praktik pengolahan produk buah melon. Semua tahapan kegiatan telah dilaksanakan dengan baik sesuai dengan rencana, termasuk tentang materi, waktu, dan hasil yang diharapkan. Materi yang diberikan meliputi cara pengolahan pangan yang baik, cara pengolahan melon, teknik pengemasan, perijinan dan pemasaran. llustrasi proses penyampaian materi dan praktik pengolahan dapat dilihat pada Gambar 1.

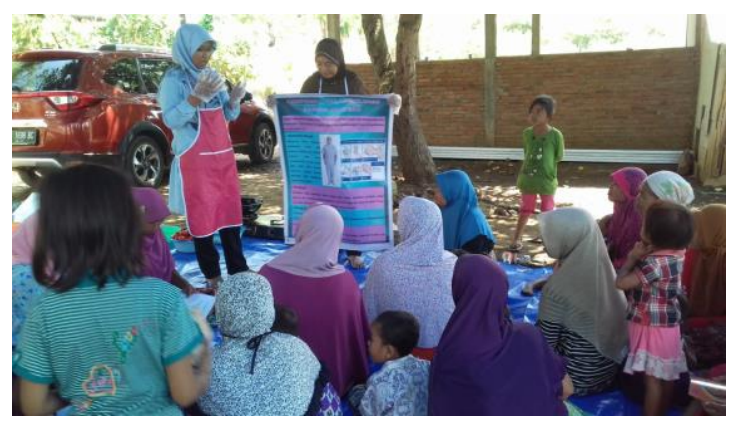

Gambar 1. Kegiatan pelatihan

Kegiatan pelatihan berjalan dengan baik dan efektif. Peserta pelatihan sangat antusias dalam mengikuti kegiatan pelatihan. Hal ini ditunjukkan dengan tingkat kehadiran peserta serta keseriusan mereka selama kegiatan. Peserta menanyakan banyak hal kepada narasumber terkait dengan pengolahan buah melon. Beberapa peserta menyatakan sangat ingin melaksanakan dan mempraktikkan pengetahuan yang diperoleh dan sangat berharap agar diberikan pembinaan lanjutan. Oleh karena itu, kegiatan pelatihan semacam ini perlu terus dilanjutkan di masa yang akan datang, tentunya dengan 
mempertimbangkan jenis produk yang disesuaikan dengan potensi daerah di lokasi kegiatan.

\section{Faktor Pendukung dan Penghambat Kegiatan Pengabdian}

Keberhasilan pelaksanaan kegiatan pengabdian ini didukung oleh beberapa faktor antara lain:

1. Antusiasme dan kesadaran peserta untuk meningkatkan kondisi perekonomian mereka. Faktor ini menggerakkan mereka untuk mengikuti kegiatan pelatihan dan kemudian mengaplikasikan ilmu dan keterampilan yang diperoleh untuk mengembangkan bisnis pengolahan buah melon. Kesadaran dan antusiasme ini merupakan hal yang penting dalam salah satu tahapan untuk penerapan teknologi atau inovasi bagi masyarakat.

2. Masyarakat di Desa Gumantar merupakan masyarakat yang suka bekerjasama dalam melaksanakan suatu kegiatan dan saling membantu untuk menyelesaikan suatu masalah yang dihadapi oleh masyarakat. Kondisi ini merupakan modal untuk maju bersama dalam suatu bisnis. Dengan kebersamaan maka banyak masalah yang bisa diselesaikan dan umumnya pekerjaan menjadi lebih ringan.

3. Kegiatan ini memberi nilai tambah bagi komoditas melon dan memberikan keuntungan. Hal ini merupakan insentif yang sangat memotivasi mereka sebagai manusia yang berfikir rasional. Nilai tambah dan keuntungan dari kegiatan pengolahan hasil melalui penerapan metode pengolahan yang lebih baik untuk menghasilkan produk yang lebih bermutu dan menguntungkan telah dapat dilihat oleh peserta kegiatan, sehingga mereka menjadi mau untuk menerapkan teknologi yang dilatihkan oleh tim.

4. Dukungan pemerintah daerah. Pemerintah daerah Kabupaten Lombok Utara (KLU) turut memfasilitasi pengembangan usaha kecil melalui penyediaan Pasar UKM sehingga masyarakat yang mengembangkan bisnis dapat memasarkan produknya. Selain itu pemerintah KLU juga memberikan dukungan permodalan melalui program wirausahawan baru. Dukungan tersebut sangat penting untuk mendukung usaha kelompok dalam memula usahanya.

\section{Faktor Penghambat}

Sebaliknya ada juga faktor penghambat kegiatan pengabdian ini. Faktor penghambat ini antara lain sebagai berikut:

1. Keterlambatan tentang pencairan dana kegiatan. Keterlambatan dana ini berakibat pada mundurnya pelaksanaan kegiatan dari jadwal yang direncanakan sehingga pelaksanaan pembinaan kurang maksimal.

2. Adanya bencana alam. Peserta pelatihan merupakan korban terdampak bencana alam yaitu gempa yang terjadi pada bulan agustus, sehingga pelaksanaan pengabdian berjalan dengan kondisi seadanya di kawasan pengungsian.

Faktor-faktor yang menghambat ini perlu dipikirkan pemecahannya, untuk menjadi pembelajaran dalam kegiatan sejenis di masa datang. Ini dimaksudkan agar kegiatan-kegiatan semacam ini dapat 
dilaksanakan secara lebih baik di masa datang.

\section{KESIMPULAN DAN SARAN}

\section{Kesimpulan}

Kegiatan pengabdian untuk pengembangan usaha pengolahan atau agroindustri produk buah melon melalui kegiatan pelatihan dan pembinaan di lapangan yang telah dilakukan berjalan dengan lancar. Anggota masyarakat yang tergabung dalam kelompok binaan sangat antusias dalam mengikuti kegiatan dan dan bersemangat untuk meneruskan pengembangan usaha pengolahan buah melon. Kegiatan pengabdian untuk pengembangan usaha pengolahan hasil pertanian terutama untuk bahan baku yang masih belum dimanfaatkan secara maksimal perlu dilakukan karena dibutuhkan oleh masyarakat sebagai upaya untuk meningkatkan nilai tambah buah melon dan sebagai sumber tambahan pendapatan bagi masyarakat. Peluang usaha di bidang pengolahan buah melon cukup terbuka. Pelatihan yang dilakukan dinilai efektif dan pelaku tergerak untuk mengaplikasikan pengetahuan dan keterampilan yang telah diperoleh dalam bentuk pengembangan usaha bisnis produk olahan melon.

\section{UCAPAN TERIMA KASIH}

Penulis mengucapkan terima kasih kepada Universitas Mataram yang telah membantu dana melalui Lembaga Penelitian dan Pengabdian Masyarakat) untuk pelaksanaan pengabdian dalam bentuk Dana DIPA PNBP (SPP/DPP/Dana Masyarakat Universitas Mataram Tahun Anggaran 2018.

\section{DAFTAR PUSTAKA}

Azna, B.N.W. 2017. Pengaruh jenis kemasan terhadap mutu keripik melon (cucumis melo l.) Selama penyimpanan. Skripsi. Fakultas Teknologi Pangan dan Agroindustri Universitas Mataram. Mataram.

Badan Pusat Statistik Provinsi NTB, 2015. Nusa Tenggara dalam Angka 2015. Mataram

Erliza dan Sutedja, 1987. Pengantar Pengemasan. Bogor: Laboratorium Pengemasan, Jurusan TIP IPB.

Robertson, L. G., 1993. Food Packaging Principles and Practice. New York: Marcel Dekker, Inc.

Samadi, B., 1995. Usaha Tani Melon. Yogyakarta: Penerbit Kanisius.

Sobir dan Siregar, 2010. Budi Daya Melon Unggul. Jakarta: Gramedia

Winarno, F.G. 1986. Kimia Pangan dan Gizi. PT. Gramedia. Jakarta 